\title{
Leptin increases serotonin turnover by inhibition of brain nitric oxide synthesis
}

\author{
Gioacchino Calapai, ${ }^{1}$ Francesco Corica, ${ }^{2}$ Andrea Corsonello, ${ }^{2}$ Lidia Sautebin, ${ }^{3}$ \\ Massimo Di Rosa, ${ }^{3}$ Giuseppe M. Campo, ${ }^{1}$ Michele Buemi, ${ }^{2}$ Vittorio Nicita Mauro, ${ }^{2}$ \\ and Achille P. Caputi ${ }^{1}$
}

${ }^{1}$ Institute of Pharmacology, School of Medicine, I-98124 Messina, Italy

${ }^{2}$ Department of Internal Medicine, School of Medicine, Policlinico Universitario, I-98124 Messina, Italy

${ }^{3}$ Department of Experimental Pharmacology, Federico II University, I-80131 Naples, Italy

Address correspondence to: Gioacchino Calapai, Institute of Pharmacology, Policlinico Universitario,

Torre Biologica, $5^{\circ}$ piano, Via Consolare Valeria, I-98124 Messina, Italy.

Phone: 39-090-221-3646; Fax: 39-090-221-2395; E-mail: coricaf@www.unime.it.

Received for publication November 20, 1998, and accepted in revised form August 24, 1999.

Leptin administration inhibits diencephalic nitric oxide synthase (NOS) activity and increases brain serotonin (5-HT) metabolism in mice. We evaluated food intake, body-weight gain, diencephalic NOS activity, and diencephalic content of tryptophan (TRP), 5-HT, hydroxyindoleacetic acid (5-HIAA), and 5-HIAA/5-HT ratio after intracerebroventricular (ICV) or intraperitoneal (IP) leptin injection in mice. Five consecutive days of ICV or IP leptin injections induced a significant reduction in neuronal NOS (nNOS) activity, and caused a dose-dependent increase of 5-HT, 5-HIAA, and the 5-HIAA/5-HT ratio. Diencephalic 5-HT metabolism showed a significant increase in 5-HT, 5-HIAA, and the 5HIAA/5-HT ratio 3 hours after a single leptin injection. This effect was maintained for 3 hours and had disappeared by 12 hours after injection. After a single IP leptin injection, the peak for 5-HT, 5HIAA, and the 5-HIAA/5-HT ratio was achieved at 6 hours. Single injections of ICV or IP leptin significantly increased diencephalic 5-HT content. Leptin-induced 5-HT increase was antagonized by the coadministration of L-arginine only when the latter was ICV injected, whereas D-arginine did not influence leptin effects on brain 5-HT content. Finally, in nNOS-knockout mice, the appetite-suppressant activity of leptin was strongly reduced, and the leptin-induced increase in brain 5-HT metabolism was completely abolished. Our results indicate that the L-arginine/NO pathway is involved in mediating leptin effects on feeding behavior, and demonstrate that nNOS activity is required for the effects of leptin on brain 5-HT turnover.

J. Clin. Invest. 104:975-982 (1999).

\section{Introduction}

The recent cloning of the mouse and human obesity genes and the characterization of their protein product, leptin (1), has introduced a new era in the field of obesity research. Leptin is a hormone exclusively produced by the adipocytes that conveys information on the size of energy stores to the brain and activates hypothalamic centers that regulate energy intake and expenditure (2). This protein also regulates feeding behavior by reducing food consumption $(3,4)$.

Several reports indicate that the hypothalamus is a critical target for the leptin satiety effects (5). Leptin has a more potent anorectic effect when administered centrally than when administered peripherally $(6,7)$. It is transported through the blood-brain barrier via a saturable transport system $(8,9)$, and achieves most of its metabolic effects by interacting with specific receptors located in the central nervous system and peripheral tissues (10-12).

The majority of studies investigating leptin-sensitive central control of food intake have focused on neuropeptide $\mathrm{Y}$, which is elevated in the hypothalamus of genetically obese mice and rats and is downregulated by leptin $(7,13)$. However, neuropeptide $Y$-knockout mice are responsive to leptin (14), indicating that neuropeptide $Y$ is not the only neurotransmitter that mediates leptin effects on food intake. Moreover, leptin seems to affect several neuroendocrine mechanisms and the hypothalamic-pituitary axis (2). To date, the specific brain pathways engaged by the hormone are still largely unknown.

Nitric oxide (NO) has been recognized as a messenger molecule in the central nervous system (15), where it mediates the increase of cGMP levels after activation of glutamate receptors of $N$-methyl-D-aspartate (16). NO has been shown to be involved in regulating ingestive behavior $(17,18)$, and inhibitors of NO synthase (NOS) activity produce anorectic effects and reduce body-weight gain when administered in both lean and obese rats (19). More recently, it has been observed that NO overproduction is reduced by leptin in cultured islets isolated from obese Zucker diabetic fatty rats (20), and intracerebroventricular (ICV) leptin injection has been reported to be capable of inhibiting diencephalic NOS activity in mice (21). 

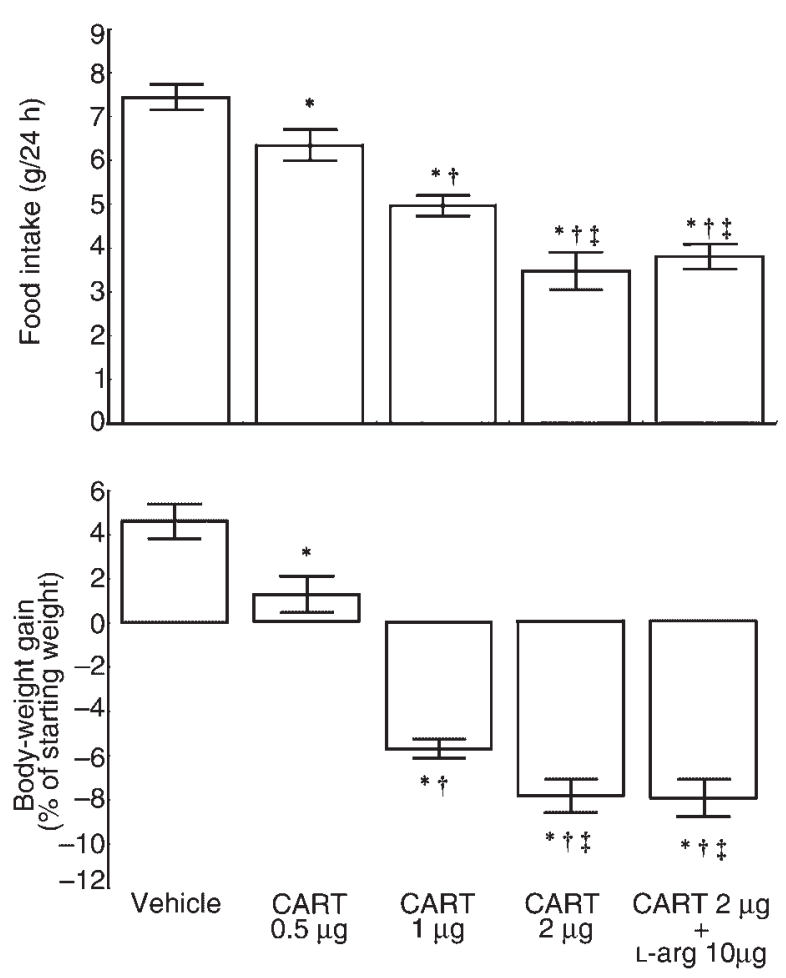

Figure 1

The effects of daily ICV injection for 5 consecutive days of vehicle, 0.5-2 $\mu$ g CART peptide (55-102), or CART peptide (55-102) + $10 \mu \mathrm{g}$ L-arginine (L-arg) on food intake and body-weight gain. Each column represents the mean \pm SEM for 6 animals. ${ }^{*} P<0.001$ vs. vehicle. ${ }^{\dagger} P<$ 0.001 vs. $0.5 \mu$ g CART peptide. $\ddagger P<0.001$ vs. $1 \mu$ g CART peptide.

Several experiments have clearly shown that serotonin (5-HT) plays a key role in the regulation of food intake $(22,23)$; drugs acting on the serotoninergic system can reduce food intake $(24,25)$. Diencephalic structures such as the medial hypothalamus - and more specifically the paraventricular, ventromedial, and suprachiasmatic nuclei - are critical regions mediating 5-HT action (26). The central serotoninergic system seems to be involved in determining NO-mediated reduction of food intake and body-weight gain (27). Moreover, it has recently been reported that intraperitoneal (IP) leptin administration increases 5-HT metabolism in the brainstem and hypothalamus of obese, but not lean, mice (28), suggesting that the satiety effect of leptin is at least partially mediated by changes in 5 -HT metabolism.

In light of these findings, we studied the relationship between leptin and the brain L-arginine/NO pathway by evaluating the effects of central and peripheral administration of leptin and L-arginine (a precursor of $\mathrm{NO}$ ) on food intake, body-weight gain, diencephalic 5-HT turnover, and neuronal NOS (nNOS) activity in mice.

\section{Methods}

Male, 8-week-old Black Swiss mice (Charles River, Italia, Calco, Milan, Italy) were used, unless otherwise stated. The animals were housed at a constant temperature of $22 \pm 2^{\circ} \mathrm{C}$ under a 12 -hour light/12-hour dark cycle (lights on at 0600 hours), with free access to Purina rat chow pellets and tap water, unless otherwise stated. The acclimation and experiments were carried out in accordance with the internationally accepted principles and the national laws of Italy concerning the care and use of laboratory animals.

For ICV injections, mice were anesthetized with IP chloral hydrate ( $400 \mathrm{mg} / \mathrm{kg}$ body weight) to produce full surgical anesthesia, and the skull was exposed. Left cerebral lateral ventricle stereotaxic coordinates for injections were $1 \mathrm{~mm}$ posterior to and $1 \mathrm{~mm}$ lateral to the bregma; depth was $2.4 \mathrm{~mm}$. Injections $(5 \mu \mathrm{L})$ were made at lambda with a 27 -gauge needle ( $3.5 \mathrm{~mm}$ long) attached to a $10-\mu \mathrm{L}$ Hamilton microsyringe (type $701 \mathrm{~N}$ ); the wound was sealed with epoxy resin. Injection of vehicle or drugs by this procedure resulted in a uniform distribution throughout the ventricular system within 10 minutes (29).

Food intake (corrected for spillage) was measured by weighing the jars containing food (to the nearest $0.1 \mathrm{~g}$ ) every 24 hours at 1000 hours; data are expressed as grams per 24 hours per mouse, unless otherwise stated. Water intake was measured using burettes (to the nearest $0.1 \mathrm{~mL}$ ). Body-weight gain was expressed as a percentage of the starting body weight.

To measure diencephalic nNOS activity, tissues were homogenized at $4^{\circ} \mathrm{C}$ in 4 volumes of HEPES buffer (20 mM; pH 7.2) containing $320 \mathrm{mM}$ sucrose, $1 \mathrm{mM}$ DL-DTT, $10 \mu \mathrm{g} / \mathrm{mL}$ soybean trypsin inhibitor, $2 \mu \mathrm{g} / \mathrm{mL}$ aprotinin, and $10 \mu \mathrm{g} / \mathrm{mL}$ leupeptin. The homogenates were centrifuged at $100,000 \mathrm{~g}$ for 30 minutes at $4^{\circ} \mathrm{C}$. The supernatants (i.e., the cytosolic fractions containing NOS activity) were stored at $-70^{\circ} \mathrm{C}$ until use. Protein concentration in the cytosolic fraction was measured spectrophotometrically according to Bradford's method, using BSA as standard (30). Activity of NOS was evaluated by measuring the rate of conversion of $\mathrm{L}-\left[\mathrm{U}-{ }^{14} \mathrm{C}\right]$ arginine to $\left[\mathrm{U}-{ }^{14} \mathrm{C}\right]$ citrulline according to the method of Salter et al. (31), and was expressed as nanomoles of citrulline per minute per gram of tissue. Briefly, an aliquot of cytosolic fraction (containing 100 mg of protein) was preincubated for 5 minutes at $37^{\circ} \mathrm{C}$ in $50 \mathrm{mM}$ potassium phosphate buffer ( $\mathrm{pH} 7.2$ ) containing $60 \mathrm{mM}$ L-valine, $120 \mu \mathrm{M} \mathrm{NADPH}, 1.2 \mathrm{mM}$ L-citrulline, $1.2 \mathrm{mM} \mathrm{MgCl}_{2}$, and $0.24 \mathrm{mM} \mathrm{CaCl}_{2}$, in the presence of drug or vehicle. Samples were then incubated for 10 minutes at $37^{\circ} \mathrm{C}$ with L- $\left[\mathrm{U}-{ }^{14} \mathrm{C}\right]$ arginine $(150,000 \mathrm{dpm})$ and $20 \mu \mathrm{M}$ L-arginine. The reaction was stopped by the addition of $1.0 \mathrm{~mL}$ of a $1: 1 \mathrm{vol} / \mathrm{vol} \mathrm{mix-}$ ture of $\mathrm{H}_{2} \mathrm{O}$ and Dowex-50W (8\% cross-linked $\mathrm{Na}^{+}$ form, Dry MESH 200-400). The $\mathrm{Na}^{+}$form of Dowex$50 \mathrm{~W}$ was prepared by washing the $\mathrm{H}^{+}$form of the resin 4 times with $1 \mathrm{M} \mathrm{NaOH}$ and then with double-distilled water until the $\mathrm{pH}$ was less than 7.5. The resin was settled by centrifugation at $11,000 \mathrm{~g}$ for 3 minutes in a Beckman Microfuge 11 (Beckman Coulter Inc., Fullerton, California, USA) and an aliquot of the supernatant was used for scintillation counting with 4 mL Pico-Fluor (Packard Instrument Co., Meriden, 
Table 1

Effects of daily injection for 5 consecutive days of leptin, L-arginine, and D-arginine on food intake and body-weight gain

\begin{tabular}{|c|c|c|}
\hline & $\begin{array}{l}\text { Food intake } \\
(\mathrm{g} / 24 \mathrm{~h})\end{array}$ & $\begin{array}{c}\text { Body-weight gain } \\
\text { (\% of starting body weight }\end{array}$ \\
\hline \multicolumn{3}{|l|}{ ICV injection } \\
\hline Vehicle & $7.7 \pm 0.6$ & $4.8 \pm 0.6$ \\
\hline Leptin $0.5 \mu \mathrm{g}$ & $7.4 \pm 0.6$ & $4.7 \pm 0.7$ \\
\hline Leptin $1 \mu \mathrm{g}$ & $4.9 \pm 0.7^{A}$ & $-9.5 \pm 0.8^{\mathrm{A}}$ \\
\hline Leptin $2 \mu \mathrm{g}$ & $4.3 \pm 0.7^{\mathrm{A}}$ & $-13.7 \pm 1.6^{A}$ \\
\hline Leptin $2 \mu \mathrm{g}+$ L-arginine $10 \mu \mathrm{g} \mathrm{ICV}$ & $6.8 \pm 1.0$ & $4.5 \pm 0.8$ \\
\hline L-arginine $10 \mu \mathrm{g} I C V$ & $7.6 \pm 0.6$ & $4.7 \pm 0.6$ \\
\hline Leptin $2 \mu \mathrm{g}+$ L-arginine $500 \mathrm{mg} / \mathrm{kg}$ IP & $4.3 \pm 0.5^{\mathrm{A}}$ & $-13.5 \pm 1.7^{\mathrm{A}}$ \\
\hline Leptin $2 \mu \mathrm{g}+\mathrm{D}$-arginine $10 \mu \mathrm{g}$ ICV & $4.4 \pm 0.6^{\mathrm{A}}$ & $-13.2 \pm 1.4^{\mathrm{A}}$ \\
\hline \multicolumn{3}{|l|}{ IP injection } \\
\hline Vehicle & $7.4 \pm 0.9$ & $4.8 \pm 0.5$ \\
\hline Leptin $5 \mu \mathrm{g}$ & $7.6 \pm 0.7$ & $4.3 \pm 0.5$ \\
\hline Leptin $10 \mu \mathrm{g}$ & $5.1 \pm 0.9^{B}$ & $-0.5 \pm 1.0^{\mathrm{B}}$ \\
\hline Leptin $20 \mu \mathrm{g}$ & $3.8 \pm 0.8^{\mathrm{B}}$ & $-1.3 \pm 1.6^{\mathrm{B}}$ \\
\hline Leptin $20 \mu \mathrm{g}+\mathrm{L}$-arginine $10 \mu \mathrm{g} \mathrm{ICV}$ & $7.1 \pm 0.7$ & $4.2 \pm 0.5$ \\
\hline L-arginine $10 \mu \mathrm{g} \mathrm{ICV}$ & $7.8 \pm 0.5$ & $4.3 \pm 0.5$ \\
\hline Leptin $20 \mu \mathrm{g}+$ L-arginine $500 \mathrm{mg} / \mathrm{kg}$ IP & $4.5 \pm 0.6^{B}$ & $-1.2 \pm 1.4^{B}$ \\
\hline Leptin $20 \mu \mathrm{g}+\mathrm{D}$-arginine $10 \mu \mathrm{g} \mathrm{ICV}$ & $4.3 \pm 0.7^{B}$ & $-1.3 \pm 1.5^{\mathrm{B}}$ \\
\hline
\end{tabular}

Data are presented as mean \pm SEM. $n=6$ for each treatment group. ${ }^{A} P<0.001$ vs. ICV vehicle, $0.5 \mu \mathrm{g}$ leptin, $2 \mu \mathrm{g}$ leptin $+10 \mu \mathrm{g}$ L-arginine, $10 \mu \mathrm{g}$ L-arginine. ${ }^{\mathrm{B} P}<0.001$ vs. vehicle, $5 \mu \mathrm{g}$ IP leptin, $20 \mu \mathrm{g}$ IP leptin $+10 \mu \mathrm{g}$ ICV L-arginine, $10 \mu \mathrm{g}$ ICV L-arginine.

Connecticut, USA). The activity of $\mathrm{Ca}^{2+}$-dependent nNOS was determined from the difference between the $\left[\mathrm{U}-{ }^{14} \mathrm{C}\right]$ citrulline produced by control samples and that produced by samples containing 1 mM EGTA. Activity of the $\mathrm{Ca}^{2+}$-independent enzyme was determined from the difference between the $\left[\mathrm{U}-{ }^{14} \mathrm{C}\right] \mathrm{cit}-$ rulline produced by samples containing 1 mM EGTA and that produced by samples containing $1 \mathrm{mM}$ EGTA and $1 \mathrm{mM} \mathrm{L}-N^{\mathrm{G}}$-monomethyl arginine.

To measure the brain levels of tryptophan (TRP), 5HT, and 5-hydroxyindoleacetic acid (5-HIAA), the cortex, diencephalon, and brainstem were homogenized in $1 \mathrm{~mL}$ of $0.3 \mathrm{~N}$ perchloric acid, as described previously (19). Cell debris was removed by centrifugation at 6,000 $g$ for 10 minutes. The pellet was discarded and the supernatant was filtered. The samples obtained were frozen at $-70^{\circ} \mathrm{C}$ until the assay. Sample contents of TRP, 5-HT, and 5-HIAA were determined using an HPLC electrochemical detection technique (32). Measurements of TRP were expressed as micromoles per gram of tissue. Measurements of 5-HT and 5-HIAA were expressed as nanomoles per gram of tissue.

Recombinant mouse leptin was a kind gift from Eli Lilly \& Co. (Lilly Corporate Center, Indianapolis, Indiana, USA). Leptin was dissolved in artificial cerebrospinal fluid (CSF) for ICV injections $(0.5-2 \mu \mathrm{g})$ and in saline for IP administration $(5-20 \mu \mathrm{g})$. Control animals received ICV or IP injection of an equal volume of CSF or saline (vehicle). $N^{\mathrm{G}}$-nitro-L-arginine, L-arginine, and D-arginine hydrochloride were obtained from
Sigma Chemical Co. (St. Louis, Missouri, USA) and dissolved in CSF for ICV injection and in saline for IP administration. $\mathrm{L}-\mathrm{N}^{\mathrm{G}}-$ monomethyl arginine was obtained from INALCO SpA (Milan, Italy). L-[U- $\left.{ }^{14} \mathrm{C}\right]$ arginine hydrochloride (specific activity 304 $\mathrm{mCi} / \mu \mathrm{mol}$ ) was obtained from Amersham International (Amersham, United Kingdom). Cocaine- and amphetamine-regulated transcript (CART) peptide (55-102) was purchased from Phoenix Pharmaceuticals Inc. (Mountain View, California, USA), and was dissolved in CSF for ICV injection.

Experiments. Daily food intake and bodyweight gain were evaluated in 3 different experiments. In the first experiment, mice were treated for 5 consecutive days with the following injections: (a) ICV vehicle, (b) 0.5 $\mu \mathrm{g}$ ICV leptin, (c) $1 \mu \mathrm{g}$ ICV leptin, (d) $2 \mu \mathrm{g}$ ICV leptin, (e) $2 \mu \mathrm{g}$ ICV leptin + $10 \mu \mathrm{g}$ ICV L-arginine, (f) $10 \mu \mathrm{g}$ ICV L-arginine, (g) $2 \mu \mathrm{g}$ ICV leptin $+500 \mathrm{mg} / \mathrm{kg} \mathrm{IP} \mathrm{L-arginine,} \mathrm{(h)} 2$ $\mu \mathrm{g} I C V$ leptin $+10 \mu \mathrm{g} I C V$ D-arginine. In the second experiment, mice were treated for 5 consecutive days as follows: (a) IP vehicle, (b) $5 \mu \mathrm{g}$ IP leptin, (c) $10 \mu \mathrm{g}$ IP leptin, (d) 20 $\mu \mathrm{g}$ IP leptin, (e) $20 \mu \mathrm{g}$ IP leptin + $10 \mu \mathrm{g}$ ICV L-arginine, (f) $10 \mu \mathrm{g}$ ICV L-arginine, (g) 20 $\mu \mathrm{g}$ IP leptin $+500 \mathrm{mg} / \mathrm{kg}$ IP L-arginine, (h) $20 \mu \mathrm{g}$ IP leptin $+10 \mu \mathrm{g} \mathrm{ICV} \mathrm{D-arginine.} \mathrm{In} \mathrm{the} \mathrm{third}$ experiment, mice were treated for 5 consecutive days with the following ICV injections: (a) vehicle, (b) $0.5 \mu \mathrm{g}$ CART peptide, (c) $1 \mu \mathrm{g}$ CART peptide, (d) $2 \mu \mathrm{g}$ CART peptide, (e) $2 \mu \mathrm{g}$ CART peptide $+10 \mu \mathrm{g}$ L-arginine.

To evaluate the effects of L-NO-arginine (an inhibitor of NOS activity) on the increased feeding characteristic of fasted animals, mice were deprived of food (but not water) for 24 hours. After this period, preweighed food was presented and consumption (expressed as grams per 100 grams of body weight) was measured by weighing the remaining amounts after 2 hours. Thirty minutes before food presentation, animals were treated as follows by ICV injection: (a) vehicle, (b) $0.25 \mu \mathrm{g}$ L-NO-arginine, (c) $0.5 \mu \mathrm{g}$ L-NO-arginine, (d) $1 \mu \mathrm{g}$ L-NO-arginine.

Neuronal diencephalic NOS activity was evaluated in 4 groups of animals after the following treatments for 5 consecutive days: (a) ICV vehicle, (b) $2 \mu \mathrm{g}$ ICV leptin, (c) IP vehicle, (d) $20 \mu \mathrm{g}$ IP leptin. Animals were sacrificed 1 hour after the last injection by decapitation under light anesthesia with ether.

Effects of central and peripheral administration of different doses of leptin on diencephalic content of TRP, 5-HT, and 5-HIAA were evaluated after 5 consecutive days of leptin injections. The experiments were performed after injections of vehicle (ICV or IP) or leptin $(0.5,1.0,1.5$, and $2.0 \mu \mathrm{g} \mathrm{ICV}$ or $5,10,15$, and $20 \mu \mathrm{g}$ IP). Animals were sacrificed 1 hour after the last injection by decapitation under light anesthesia with ether. 


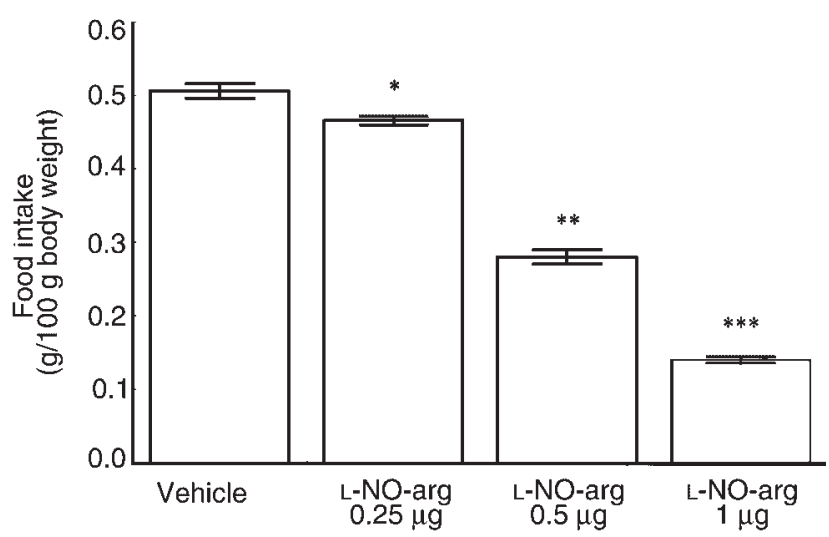

Figure 2

The effects of pretreatment (30 minutes before food presentation) with ICV injection of L-NO-arginine $(0.25-1 \mu \mathrm{g})$ on starvationinduced food intake. Each column represents the mean \pm SEM for 6 animals. ${ }^{*} P<0.001$ vs. vehicle. ${ }^{*} P<0.001$ vs. vehicle or $0.25 \mu \mathrm{g} \mathrm{L}-$ NO-arginine. ${ }^{* *} P<0.001$ vs. vehicle, $0.25 \mu \mathrm{g}$ L-NO arginine, or 0.5 $\mu \mathrm{g}$ L-NO-arginine.

The time course for TRP, 5-HT, 5-HIAA, and the 5HIAA/5-HT molar ratio was evaluated after a single administration of leptin, injected centrally $(2 \mu \mathrm{g} I C V)$ or peripherally $(20 \mu \mathrm{g} \mathrm{IP})$. Animals were sacrificed at the following time points: baseline (time 0), 0.5 hours, 1 hour, 3 hours, 6 hours, and 12 hours.

To evaluate the involvement of the brain L-arginine/NO pathway in the leptin effects on diencephalic 5-HT content, we performed 2 experiments. In the first, mice were treated as follows: (a) ICV vehicle, (b) $2 \mu \mathrm{g}$ ICV leptin, (c) $2 \mu \mathrm{g}$ ICV leptin $+10 \mu \mathrm{g} \mathrm{ICV} \mathrm{L-arginine,}$ (d) $2 \mu \mathrm{g}$ ICV leptin $+500 \mathrm{mg} / \mathrm{kg}$ IP L-arginine, (e) $2 \mu \mathrm{g}$ ICV leptin $+10 \mu \mathrm{g} \mathrm{ICV} \mathrm{D-arginine.} \mathrm{In} \mathrm{the} \mathrm{second} \mathrm{exper-}$ iment, the following treatment was performed: (a) IP vehicle, (b) $20 \mu \mathrm{g}$ IP leptin, (c) $20 \mu \mathrm{g}$ IP leptin $+10 \mu \mathrm{g}$ ICV L-arginine, (d) $20 \mu \mathrm{g}$ IP leptin $+500 \mathrm{mg} / \mathrm{kg} \mathrm{IP} \mathrm{L-}$ arginine, (e) $20 \mu \mathrm{g}$ IP leptin + $10 \mu \mathrm{g}$ ICV D-arginine. Animals were sacrificed 1 hour after the injections by decapitation under light anesthesia with ether.

Finally, the effects of central leptin administration on food intake, body-weight gain, and diencephalic content of TRP, 5-HT, and 5-HIAA were evaluated in nNOS-null mice. Male, 8-week-old B6/129S-Nos1 $1^{\text {tm1Pth }}$ mice and B6/129SF2 wild-type controls (Charles River Italia) were used. Food intake and body-weight gain were measured after 5 consecutive days of ICV leptin (2 $\mu \mathrm{g})$ or vehicle injection. Additionally, diencephalic content of TRP, 5-HT, and 5-HIAA was evaluated after a single ICV leptin $(2 \mu \mathrm{g})$ or vehicle injection. Animals were sacrificed 6 hours after the injection by decapitation under light anesthesia with ether.

At the end of each experiment, the brain was rapidly removed and the diencephalon was quickly dissected out and immediately frozen in liquid nitrogen until the assays.

Statistical analysis. All statistical procedures were performed using SPSS statistical software, version 7.5
(SPSS Inc., Chicago, Illinois, USA). Data analysis was performed using the ANOVA 1-way test, with the Scheffe post hoc test for multiple comparisons when appropriate. Each group of animals was composed of 6 mice in all experiments. Data are expressed as mean \pm SEM. Statistical significance was set at $P<0.05$.

\section{Results}

Data on the effects of leptin on food intake and bodyweight gain are summarized in Table 1. A significant reduction in food intake and body-weight gain was induced by the highest doses of leptin ( 1 and $2 \mu \mathrm{g} \mathrm{ICV}$, and 10 and $20 \mu \mathrm{g}$ IP). Effects induced by ICV or IP leptin were completely eliminated by ICV L-arginine. However, the IP administration of L-arginine $(500 \mathrm{mg} / \mathrm{kg})$ did not modify the effects of leptin (ICV or IP) on food intake and body-weight gain. The stereoisomer D-arginine did not modify the effects of leptin on food intake and body-weight gain.

CART peptide (55-102) ICV injection $(0.5-2 \mu \mathrm{g})$ caused a dose-dependent reduction in food intake and body-weight gain. Coadministration of L-arginine did not influence the effects of CART peptide (Figure 1).

Another experiment was performed to evaluate the effects of a single ICV injection of L-NO-arginine on starvation-induced feeding behavior. After 24 hours of food deprivation, ICV administration of L-NO-arginine caused a significant and dose-dependent reduction in food consumption (Figure 2).

Measurement of diencephalic nNOS activity revealed only the presence of $\mathrm{Ca}^{2+}$-dependent constitutive nNOS. Mice treated for 5 consecutive days with ICV (2 $\mu \mathrm{g})$ and IP $(20 \mu \mathrm{g})$ leptin injections showed a significant reduction in nNOS activity compared with animals treated with vehicle (Figure 3).

The experiment performed to evaluate the effects of consecutive doses $(0.5-2 \mu \mathrm{g})$ of ICV leptin on 5-HT turnover showed a dose-dependent increase of 5-HT, 5-HIAA, and the 5-HIAA/5-HT ratio that was apparent

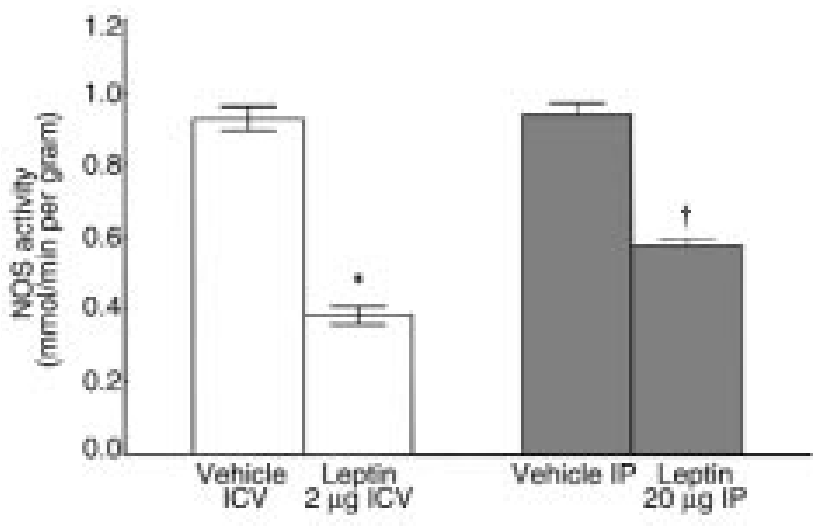

Figure 3

The effect of daily leptin injection for 5 consecutive days ( $2 \mu \mathrm{g} \mathrm{ICV}$ or $20 \mu \mathrm{g}$ IP) on diencephalic NOS activity. Each column represents the mean \pm SEM for 6 animals. ${ }^{*} P<0.001$ vs. vehicle ICV. ${ }^{\dagger} P<$ 0.001 vs. IP vehicle. 
Table 2

The effects of daily ICV or IP injection of leptin for 5 consecutive days on 5-HT metabolism

$$
\text { TRP }(\mu \mathrm{mol} / \mathrm{g}) \quad 5-\mathrm{HT}(\mathrm{nmol} / \mathrm{g}) \quad 5-\mathrm{HIAA}(\mathrm{nmol} / \mathrm{g}) 5-\mathrm{HIAA} / 5-\mathrm{HT}
$$

ICV injection

$\begin{array}{ccccc}\text { Vehicle } & 0.94 \pm 0.07 & 4.6 \pm 0.4 & 5.0 \pm 0.4 & 1.09 \pm 0.01 \\ \text { Leptin } 0.5 \mu \mathrm{g} & 0.96 \pm 0.06 & 5.1 \pm 0.3 & 5.4 \pm 0.3 & 1.07 \pm 0.02 \\ \text { Leptin } 1 \mu \mathrm{g} & 0.90 \pm 0.05 & 9.8 \pm 0.5^{\mathrm{A}} & 12.1 \pm 0.3^{\mathrm{A}} & 1.24 \pm 0.03^{\mathrm{B}} \\ \text { Leptin } 1.5 \mu \mathrm{g} & 1.02 \pm 0.07 & 12.6 \pm 0.5^{\mathrm{A}, \mathrm{C}} & 16.7 \pm 0.6^{\mathrm{A}, \mathrm{E}} & 1.32 \pm 0.03^{\mathrm{A}} \\ \text { Leptin } 2 \mu \mathrm{g} & 0.98 \pm 0.08 & 16.5 \pm 1.0^{\mathrm{A}, \mathrm{D}, \mathrm{F}} & 22.2 \pm 0.8^{\mathrm{A}, \mathrm{E}, \mathrm{G}} & 1.36 \pm 0.05^{\mathrm{A}} \\ \text { IP injection } & & & & \\ \quad & & & \\ \text { Vehicle } & 0.98 \pm 0.07 & 4.8 \pm 0.3 & 5.3 \pm 0.2 & 1.10 \pm 0.02 \\ \text { Leptin } 5 \mu \mathrm{g} & 0.96 \pm 0.07 & 5.5 \pm 0.3 & 6.1 \pm 0.3 & 1.14 \pm 0.02 \\ \text { Leptin } 10 \mu \mathrm{g} & 0.94 \pm 0.07 & 8.5 \pm 0.4^{\mathrm{H}} & 10.6 \pm 0.3^{\mathrm{H}} & 1.25 \pm 0.02^{\mathrm{J}} \\ \text { Leptin } 15 \mu \mathrm{g} & 0.99 \pm 0.08 & 11.1 \pm 0.4^{\mathrm{H}, \mathrm{K}} & 14.1 \pm 0.4^{\mathrm{H}, \mathrm{L}} & 1.27 \pm 0.03^{\prime} \\ \text { Leptin } 20 \mu \mathrm{g} & 0.92 \pm 0.08 & 13.6 \pm 0.5^{\mathrm{H}, \mathrm{L}, \mathrm{M}} & 18.4 \pm 0.5^{\mathrm{H}, \mathrm{L}, \mathrm{N}} & 1.35 \pm 0.05^{\mathrm{H}}\end{array}$

Data are presented as mean \pm SEM. $n=6$ for each treatment group. ${ }^{A} P<0.001,{ }^{B} P<0.05$ vs. vehicle or $0.5 \mu \mathrm{g} \mathrm{ICV}$ leptin. ${ }^{C} P<0.05$, ${ }^{D} P<0.01, \mathrm{E} P<0.001$ vs. $1 \mu \mathrm{g}$ ICV leptin. ${ }^{\mathrm{F} P}<0.01,{ }^{\mathrm{G}} P<$ 0.001 vs. $1.5 \mu \mathrm{g} \mathrm{ICV}$ leptin. ${ }^{H} P<0.001, \mid P<0.01, \mathrm{~J} P<0.05$ vs. vehicle or $5 \mu \mathrm{g}$ IP leptin. ${ }^{K} P<0.01$, $\left\llcorner P<0.001\right.$ vs. $10 \mu \mathrm{g}$ IP leptin. ${ }^{M} P<0.01, N P<0.001$ vs. $15 \mu \mathrm{g}$ IP leptin.

at a dose of $1 \mu \mathrm{g}$, whereas TRP remained unchanged (Figure 4). Similar results were obtained when consecutive doses $(5-20 \mu \mathrm{g})$ of leptin were peripherally administered (Table 2).

The time courses of the ICV and IP leptin effects on diencephalic 5-HT metabolism are reported in Figure 4. In this experiment, TRP was unchanged at all time points with respect to baseline, whereas significant increases in 5-HT, 5-HIAA, and the 5-HIAA/5-HT ratio were found 3 hours after a single $(2 \mu \mathrm{g})$ ICV leptin injection; these increases were maintained for 3 hours. This effect disappeared at 12 hours after injection. When the experiment was carried out with a single $(20 \mu \mathrm{g})$ IP leptin injection, the peak levels for 5-HT, 5-HIAA, and the 5-HIAA/5-HT ratio were achieved at 6 hours.

The experiments performed to evaluate the involvement of the brain L-arginine/NO pathway in the leptin effects on diencephalic 5-HT content showed that either ICV $(2 \mu \mathrm{g})$ or IP $(20 \mu \mathrm{g})$ leptin administration significantly increased diencephalic 5-HT content. The effects of leptin on 5-HT were antagonized by the coadministration of L-arginine only when the latter was ICV injected. In the group treated with D-arginine, the effects of leptin on brain 5-HT content were unchanged (Figure 5).

Finally, the effects of central leptin administration on food intake and body-weight gain were evaluated in nNOS-knockout mice (B6/129S-Nos1 $\left.1^{\text {tm1Pth }}\right)$ and their wild-type counterparts (B6/129SF2). Five consecutive days of ICV leptin administration $(2 \mu \mathrm{g})$ caused a significant reduction of food intake and body-weight gain in wild-type mice, similar to that observed in Swiss mice. In contrast, the effects of leptin on food intake and bodyweight gain were only partially detectable in nNOSknockout mice. (Figure 6). Furthermore, a single ICV leptin injection caused a significant increase of 5-HT, 5HIAA, and the 5-HIAA/5-HT ratio in wild-type mice, whereas the leptin-induced increase in brain 5-HT turnover was completely abolished in nNOS-knockout mice (Table 3).

\section{Discussion}

Considerable evidence suggests the involvement of $\mathrm{NO}$ in central nervous system functions, such as neuroendocrine regulation (33), long-term potentiation (34), and ingestive behavior $(35,36)$. NOS is the enzyme that oxidizes the guanidino group of L-arginine in a process that uses 5 electrons and coproduces NO and citrulline (37). NOS can be classified into 3 isoforms -2 constitutive and 1 inducible (38). nNOS is constitutive and $\mathrm{Ca}^{2+}$ dependent (39), and is relatively highly expressed in the diencephalic region, in particular in the hypothalamic paraventricular and supraoptic nuclei $(40,41)$.

We previously reported that central leptin administration reduces diencephalic nNOS activity. This effect is dose-dependent (with $1 \mu \mathrm{g}$ being the lowest ICV dose having a measurable effect) and long-lasting (inhibition of nNOS activity starts $30 \mathrm{~min}$ utes after a single ICV leptin injection, and is still present after 12 hours) (21). In this study, we investigated the effects of either central (ICV) or peripheral (IP) leptin administration on diencephalic nNOS activity. Our results confirm that central and peripheral leptin administration both reduce food intake and body-weight gain, and show that these effects can be antagonized by ICV pretreatment with the amino acid L-arginine, which is a precursor of NO. Leptin effects on food intake and bodyweight gain are not modified when L-arginine is peripherally injected, suggesting an interaction between leptin and the brain L-arginine/NO pathway in regulating food intake and body-weight gain. Furthermore, the stereoisomer D-arginine was not able to influence leptin effects on food intake and body-weight gain, thus excluding the possibility that the administration of $\mathrm{L}$ arginine may exert a nonspecific effect on feeding behavior independent of $\mathrm{NO}$ formation. Interestingly, the fact that L-arginine apparently restores NO synthesis could be due to direct or indirect competition with leptin for the same sites involved in regulating NO synthesis. Furthermore, the possibility that L-arginine in excess may activate alternative pathways leading to NO synthesis, such as arginases (42), cannot be ruled out.

CART peptides are anorectic agents that influence the hypothalamic circuitry regulating food intake (43). ICV injection of CART peptide in rodents inhibits normal and starvation-induced feeding behavior $(44,45)$. Moreover, the administration of an antiserum against CART peptide increases food intake in unfasted rats, indicating that CART peptide may be an endogenous appetite-suppressing agent (44). In our experiments, we used CART peptide (55-102) as a pharmacological tool to investigate whether L-arginine-treated animals still respond to 

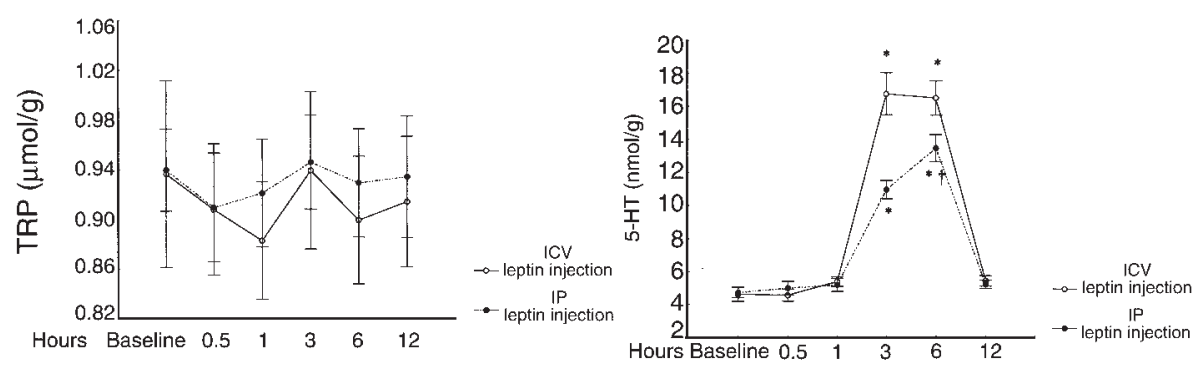

Figure 4

Time course of TRP, 5-HT, and 5HIAA diencephalic content and 5HIAA/5-HT ratio after ICV $(2 \mu \mathrm{g})$ or IP $(20 \mu \mathrm{g})$ leptin injection. Each time point represents the mean \pm SEM for 6 animals. ${ }^{*} P<0.001,{ }^{*} P$ $<0.01$ vs. baseline, 0.5 hour, 1 hour, 12 hours. ${ }^{\dagger} P<0.001$, ${ }^{\dagger} P<$ 0.01 vs. 3 hours.
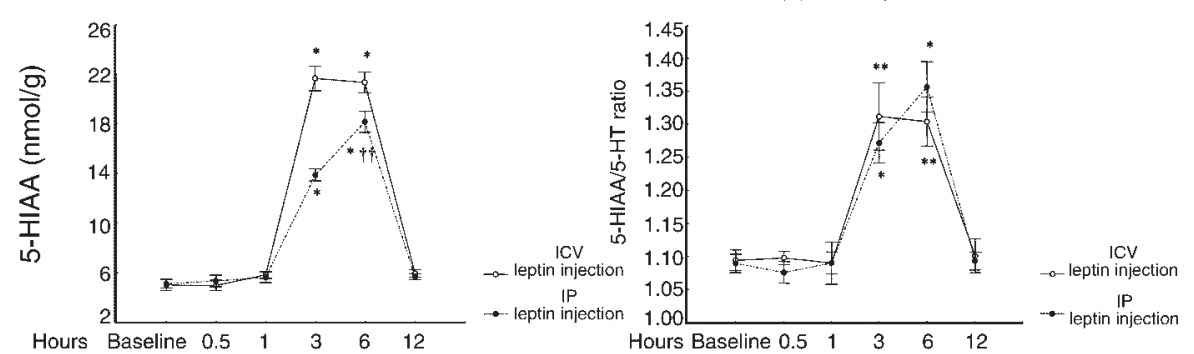

anorexigenic agents other than leptin. We found that Larginine is not able to influence CART peptide (55-102) anorectic effects. Because L-arginine reduces anorectic effects of leptin, but not of CART peptide, we suggest a possible specific link between leptin and brain NO in regulating feeding behavior.

Two other observations seem to confirm that NO plays a key role in regulating feeding behavior. First, it is known that food deprivation increases brain NOS activity (46). Second, the experiments described in this paper show that ICV administration of L-NO-arginine, a selective and powerful inhibitor of brain NOS (47), causes a significant reduction in starvation-induced food intake compared with vehicle-treated fasted animals.

The inhibitors of brain NO formation and leptin share similar effects on food intake, body-weight gain, and brain NOS activity $(19,21)$. The regulation of food intake and energy balance is controlled by neuronal systems converging on the ventral hypothalamus; lesions in this region alter regulation of body weight (48). Several studies focused on the serotoninergic system have demonstrated that hypothalamic serotoninergic activity contributes to central regulation of food intake and energy balance $(49,50)$. Metabolic rate is increased and food intake is reduced after treatment with systemically administered drugs that are known to increase brain 5-HT levels, such as fenfluramine, fluoxetine, and sertraline (51-53).

Furthermore, central administration of 5-HT into the paraventricular or ventromedial hypothalamic nuclei produces an increase of firing rates of sympathetic nerves to brown adipose tissue (54). A recent report showed that systemically injected low doses $(2 \mu \mathrm{g} / \mathrm{d})$ of leptin increase 5-HT metabolism in the hypothalamus of $o b / o b$ mice, whereas the same doses are ineffective in lean mice. Thus, it has been hypothesized that the satiety effect of leptin in obese mice is partially mediated by modulation of 5-HT metabolism (28). It has also been shown that the administration of inhibitors of brain NO formation produces a decrease in food intake and bodyweight gain and a concurrent rise in serotoninergic activity (27). Thus, we speculated that 5-HT metabolism could be involved in central leptin effects.

In our experiments, central and peripheral leptin administration stimulated diencephalic serotoninergic activity. Because TRP diencephalic content is not modified by injection of either ICV or IP leptin, one could hypothesize that the leptin-induced increase in 5-HT turnover could be explained by an increased release or a decreased reuptake of $5-\mathrm{HT}$, and the rise in the 5HIAA/5-HT ratio observed in leptin-treated mice is a further marker of increased 5-HT turnover (55). Moreover, the time course of leptin effects on diencephalic 5HT turnover indicates that there is a latency period after leptin administration before the appearance of leptin effects on 5-HT metabolism. Finally, the differences observed in the effects of leptin on 5-HT turnover when centrally or peripherally injected can probably be explained by the fact that central administration delivers a direct injection of leptin into the central nervous system, whereas peripherally injected leptin needs to
Table 3

Effects of a single ICV leptin $(2 \mu \mathrm{g})$ or vehicle injection on 5-HT metabolism in nNOS-knockout mice (B6/129S-Nos1 $\left.{ }^{\text {tm } 1 \text { Pth }}\right)$ and their wild-type counterparts (B6/129SF2)

\begin{tabular}{|c|c|c|c|c|}
\hline & \multicolumn{2}{|c|}{ nNOS-knockout mice } & \multicolumn{2}{|c|}{ nNOS wild-type mice } \\
\hline & Vehicle & Leptin $2 \mu \mathrm{g}$ ICV & Vehicle & Leptin $2 \mu \mathrm{g}$ ICV \\
\hline TRP $(\mu \mathrm{mol} / \mathrm{g})$ & $0.96 \pm 0.05$ & $1.01 \pm 0.04$ & $0.97 \pm 0.03$ & $0.99 \pm 0.06$ \\
\hline 5-HT (nmol/g) & $4.82 \pm 0.29$ & $4.80 \pm 0.52$ & $4.90 \pm 0.25$ & $18.0 \pm 0.84^{A, B}$ \\
\hline 5-HIAA (nmol/g) & $5.30 \pm 0.25$ & $5.12 \pm 0.49$ & $5.17 \pm 0.20$ & $21.9 \pm 0.94^{\mathrm{A}, \mathrm{B}}$ \\
\hline 5-HIAA/5-HT & $1.10 \pm 0.02$ & $1.07 \pm 0.02$ & $1.06 \pm 0.03$ & $1.21 \pm 0.03^{\mathrm{A}, \mathrm{B}}$ \\
\hline
\end{tabular}

Data are mean \pm SEM. $n=6$ for each group. ${ }^{A} P<0.001$ vs. vehicle. ${ }^{B} P<0.001$ vs. nNOS-knockout mice. 


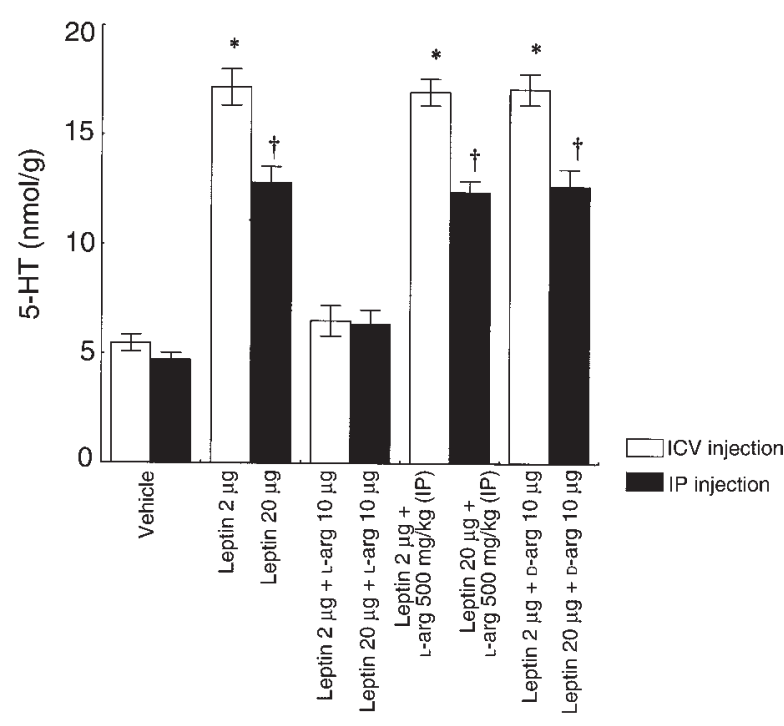

Figure 5

The effects of 5 consecutive days of treatment with ICV or IP vehicle, leptin, leptin + L-arginine, or leptin + D-arginine on brain 5-HT content. Each column represents the mean \pm SEM for 6 animals. ${ }^{*} P<$ 0.001 vs. vehicle or $2 \mu \mathrm{g}$ ICV leptin $+10 \mu \mathrm{g} \mathrm{ICV} \mathrm{L-arginine.}{ }^{\dagger} P<0.001$ vs. vehicle or $20 \mu \mathrm{g}$ IP leptin $+10 \mu \mathrm{g}$ ICV L-arginine.

reach diencephalic structures before it is able to modify 5-HT metabolism. Our results seem to be consistent with those reported by Harris et al. (28), and show that peripheral administration of higher doses $(10 \mu \mathrm{g} / \mathrm{d}$ or more) of leptin produces an increase in 5-HT metabolism in nonobese mice similar to what has been observed in obese mice.

The mechanisms linking the effects of leptin to the increase in serotoninergic activity have not been studied. The inhibitory effect of leptin on NOS activity, together with the observation that the precursor of $\mathrm{NO}, \mathrm{L}$-arginine, is able to antagonize leptin effects on food intake and body-weight gain, suggests that the $o b$ gene product could modulate serotoninergic system activity through its inhibitory action on diencephalic nNOS activity. This hypothesis seems to be confirmed by the experiments performed to evaluate the effects of leptin and L-arginine on diencephalic content of 5-HT. Data from this experiment show that ICV L-arginine, but not $\mathrm{D}$-arginine, antagonizes leptin effects on 5-HT turnover. These results are consistent with those obtained in the experiment performed to investigate the effects of this treatment on food intake and body-weight gain. Furthermore, peripheral administration of L-arginine does not alter leptin effects on food intake, body-weight gain, or 5HT turnover, indicating that these effects of leptin could be mediated by inhibition of NO formation in the central nervous system.

Finally, the results from the experiments performed with nNOS-null mice also support our hypothesis that NO plays a key role in mediating central leptin effects. Although a small leptin-induced reduction of food intake and body-weight gain was still present, it was strongly inhibited in nNOS-knockout mice compared with wild-type animals. These results suggest that the appetite-suppressing activity of leptin may partially depend upon its inhibitory effect on brain NO synthesis. Furthermore, leptin effect on 5-HT turnover was completely erased in nNOS-knockout mice, whereas it was still detectable in wild-type controls, indicating that nNOS activity is required for leptin to affect 5 -HT turnover. To the best of our knowledge, these results have not been reported before. Our data from experiments with nNOS-knockout mice definitively support a role for $\mathrm{NO}$ in central leptin anorectic action.

We conclude that the brain L-arginine/NO pathway is involved in leptin effects on food intake and bodyweight gain. Unquestionably, NO cannot be considered the only mediator of these effects, because there is evidence for the existence of a number of appetite-regulating systems (56). However, the results of this study indicate that leptin-induced inhibition of brain $\mathrm{NO}$ synthesis is involved in determining leptin effects on central regulation of feeding behavior. Furthermore, both central and peripheral leptin administration cause an increase in 5-HT turnover, and the experiments reported in this paper demonstrate for the first time that nNOS activity is required for the effects of leptin on 5-HT turnover in the brain.
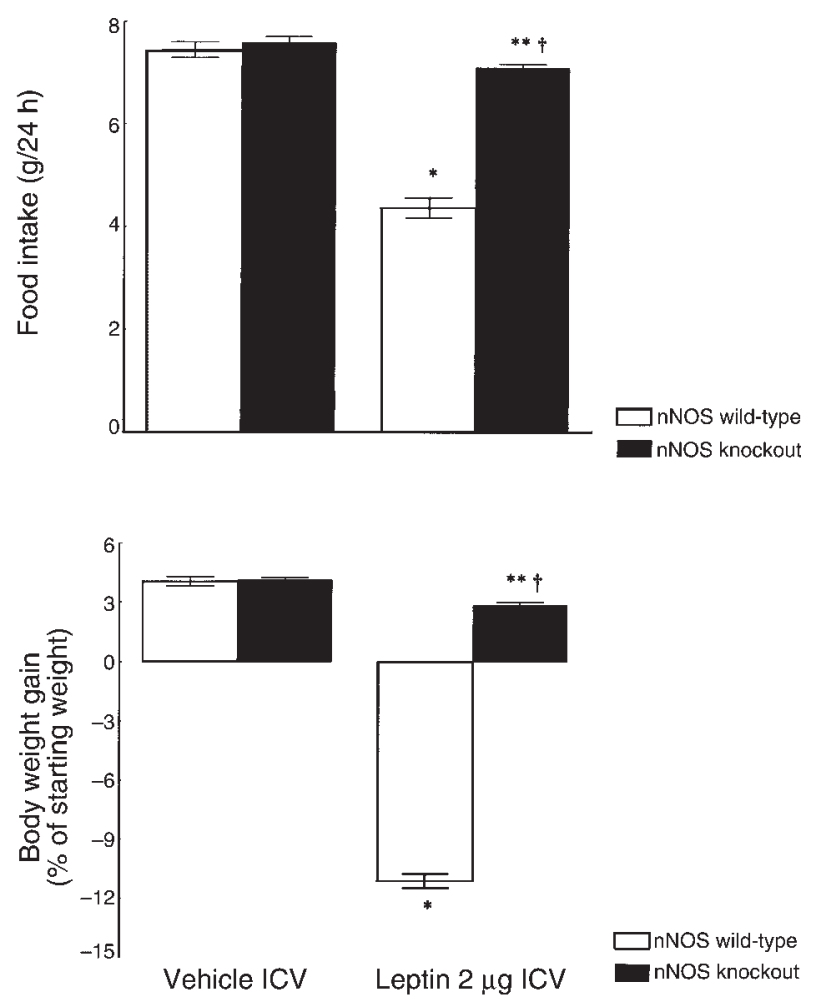

Figure 6

The effects of 5 consecutive days of treatment with leptin $(2 \mu \mathrm{g})$ or vehicle on food intake and body-weight gain in nNOS-knockout mice (B6/129S-Nos1 $\left.1^{\text {tm 1Pth }}\right)$ and their wild-type counterparts (B6/129SF2). Each column represents the mean \pm SEM for 6 animals. ${ }^{*} P<0.001$, ${ }^{*} P<0.01$ vs. vehicle. ${ }^{\dagger} P<0.001$ vs. nNOS wild-type. 


\section{Acknowledgments}

This work was supported by grants from Ministero Università, Ricerca Scientifica e Technologica (MURST).

1. Zhang, Y., et al. 1994. Positional cloning of the mouse obese gene and its human homologue. Nature. 372:425-432.

2. Flier, J.S. 1997. Leptin expression and action: new experimental paradigms. Proc. Natl. Acad. Sci. USA. 94:4242-4245.

3. Pelleymounter, M.A., et al. 1995. Effects of the obese gene product on body weight regulation in ob/ob mice. Science. 269:540-543.

4. Tritos, N.A., and Mantzoros, C.S. 1997. Leptin: its role in obesity and beyond. Diabetologia. 40:1371-1379.

5. Auwerx, J., and Staels, B. 1998. Leptin. Lancet. 351:737-742.

6. Campfield, L.A., Smith, F.J., Guisez, Y., Devos, R., and Burn, P. 1995. Recombinant mouse Ob protein; evidence for a peripheral signal linking adiposity and central neural networks. Science. 269:546-549.

7. Stephens, T.W., et al. 1995. The role of neuropeptide Y in the antiobesity action of the obese gene product. Nature. 377:530-532.

8. Baumann, H., et al. 1996. The full length leptin receptor has signalling capabilities of interleukin 6-type receptors. Proc. Natl. Acad. Sci. USA. 93:8374-8378.

9. Montague, C.T., et al. 1997. Congenital leptin deficiency is associated with severe early-onset obesity in humans. Nature. 387:903-908.

10. Tartaglia, L.A., et al. 1995. Identification and expression cloning of a leptin receptor, Ob-R. Cell. 83:1263-1271.

11. Lee, G.H., et al. 1996. Abnormal splicing of the leptin receptor in diabetic mice. Nature. 379:632-635

12. Chen, H., et al. 1996. Evidence that the diabetes gene encodes the leptin receptor: identification of a mutation in the leptin receptor gene in $\mathrm{db} / \mathrm{db}$ mice. Cell. 84:491-495.

13. Schwartz, M.W., et al. 1996. Specificity of leptin action on elevated blood glucose levels and hypothalamic neuropeptide $\mathrm{Y}$ gene expression in ob/ob mice. Diabetes. 45:531-535.

14. Erickson, J.C., Clegg, K.E., and Palmiter, R.D. 1996. Sensitivity to leptin and susceptibility to seizures of mice lacking neuropeptide Y. Nature. 381:415-421.

15. Garthwaite, J., Charles, S.L., and Chess-Williams, R. 1988. Endotheliumderived relaxing factor release on activation of NMDA receptors suggests a role as intercellular messenger in the brain. Nature. 336:385-388.

16. Garthwaite, J., and Boulton, C.L. 1995. Nitric oxide signaling in the central nervous system. Annu. Rev. Physiol. 57:683-706.

17. Calapai, G., et al. 1992. Evidence that nitric oxide modulates drinking behaviour. Neuropharmacology. 31:761-764.

18. Morley, J.E., and Flood, J.F. 1991. Evidence that nitric oxide modulates food intake in mice. Life Sci. 49:707-711.

19. Squadrito, F., et al. 1993. Anorectic activity of $\mathrm{N}^{\mathrm{G}}$-nitro-L-arginine, an inhibitor of brain nitric oxide synthase, in obese Zucker rats. Eur. J. Pharmacol. 230:125-128.

20. Wang, M.Y., Koyama, K., Shimabukuro, M., Newgard, C.B., and Unger, R.H. 1998. OB-Rb gene transfer to leptin-resistant islets reverses diabetogenic phenotype. Proc. Natl. Acad. Sci. USA. 95:714-718.

21. Calapai, G., et al. 1998. Effects of intracerebroventricular leptin administration on food intake, body-weight gain and diencephalic nitric oxide synthase activity in the mouse. Br. J. Pharmacol. 125:798-802.

22. Blundell, J.E. 1984. Serotonin and appetite. Neuropharmacology. 23:1537-1551.

23. Leibowitz, S.F. 1990. The role of 5-HT in eating disorders. Drugs. 39(Suppl. 3):33-48

24. Garattini, S. 1995. Biological actions of drugs affecting 5-HT and eating. Obes. Res. 3(Suppl. 4):463S-470S

25. Cerulli, J., Lomaestro, B.M., and Malone, M. 1998. Update on the pharmacotherapy of obesity. Ann. Pharmacother. 32:88-102

26. Leibowitz, S.F., Weiss, G.F., and Shor-Posner, G. 1988. Hypothalamic serotonin: pharmacological, biochemical, and behavioral analyses of its feeding-suppressive action. Clin. Neuropharmacol. 11(Suppl. 1):S51-S71.

27. Squadrito, F., et al. 1994. Central serotoninergic system involvement in the anorexia induced by $N^{G}$-nitro-L-arginine, an inhibitor of nitric oxide synthase. Eur. J. Pharmacol. 255:51-55.

28. Harris, R.B., et al. 1998. A leptin dose-response study in obese (ob/ob) and lean (+/?) mice. Endocrinology. 139:8-19.

29. De Sarro, G., et al. 1992. Effects of antiepileptic drugs, calcium channel blockers and other compounds on seizures induced by activation of voltage-dependent L-calcium channel in DBA/2 mice. Gen. Pharmacol.
23:1205-1216.

30. Bradford, M.M. 1976. A rapid method for quantitation of protein dye binding. Anal. Biochem. 72:248-254.

31. Salter, M., Knowles, R.G., and Moncada, S. 1991. Widespread tissue distribution, species distribution and changes in activity of $\mathrm{Ca}^{2+}$-independent nitric oxide synthase. FEBS Lett. 291:145-149.

32. Squadrito, F., et al. 1991. Indolepyruvic acid, a tryptophan keto analogue, reduces food intake in obese Zucker rats. Neurosci. Res. Commun. 9:27-36.

33. Costa, A., Trainer, P., Besser, M., and Grossman, A. 1993. Nitric oxide modulates the release of corticotropin-releasing hormone from the rat hypothalamus in vitro. Brain Res. 605:187-192.

34. Haley, J.E., Wilcox, G.L., and Chapman, P.F. 1992. The role of nitric oxide in hippocampal long-term potentiation. Neuron. 8:211-216.

35. Calapai, G., and Caputi, A.P. 1996. Nitric oxide and drinking behaviour. Regul. Pept. 66:117-121.

36. Stricker-Krongrad, A., Beck, B., and Burlet, C. 1996. Nitric oxide mediates hyperphagia of obese Zucker rats: relation to specific changes in the microstructure of feeding behavior. Life Sci. 58:9-15.

37. Zhang, J., and Snyder, S.H. 1995. Nitric oxide in the nervous system. Annu. Rev. Pharmacol. Toxicol. 35:213-233.

38. Förstermann, U., and Kleinert, H. 1995. Nitric oxide synthase: expression and expressional control of the three isoforms. Naunyn Schmiedebergs Arch. Pharmacol. 352:351-364.

39. Fukuto, J.M., and Chauduri, G. 1995. Inhibition of constitutive and inducible nitric oxide synthase: potential selective inhibition. Annu. Rev. Pharmacol. Toxicol. 35:165-194.

40. Bredt, D.S., Hwang, P.M., and Snyder, S.H. 1990. Localization of nitric oxide synthase indicating a neural role for nitric oxide. Nature. 347:768-770.

41. Dawson, T.M., Bredt, D.S., Fotuhi, M., Hwang, P.M., and Snyder, S.H. 1991. Nitric oxide synthase and neuronal NADPH diaphorase are identical in brain and peripheral tissues. Proc. Natl. Acad. Sci. USA. 88:7797-7801.

42. Wu, G., and Morris, S.M. 1998. Arginine metabolism: nitric oxide and beyond. Biochem. J. 336:1-17.

43. Thim, L., et al. 1998. Purification and characterisation of a new hypothalamic satiety peptide, cocaine and amphetamine regulated transcript (CART), produced in yeast. FEBS Lett. 428:263-268.

44. Kristensen, P., et al. 1998. Hypothalamic CART is a new anorectic peptide regulated by leptin. Nature. 393:72-76.

45. Lambert, P., et al. 1998. CART peptides in the central control of feeding and interactions with neuropeptide Y. Synapse. 29:293-298.

46. Squadrito, F., et al. 1994. Food deprivation increases brain nitric oxide synthase and depresses brain 5-HT levels in rats. Neuropharmacology. 33:83-86.

47. Dwyer, M.A., Bredt, D.S., and Snyder, S.H. 1991. Nitric oxide synthase: irreversible inhibition by $\mathrm{L}-\mathrm{N}^{\mathrm{G}}$-nitroarginine in brain in vitro and in vivo. Biochem. Biophys. Res. Commun. 176:1136-1141.

48. Bray, G.A. 1991. Obesity, a disorder of nutrient partitioning: the MONA LISA hypothesis. J. Nutr. 121:1146-1162.

49. Fuller, N.J., Stirling, D.M., Dunnett, S., Reynolds, B.P., and Ashwell, M. 1987. Decreased brown adipose tissue thermogenic activity following a reduction in brain 5-HT by intraventricular p-chlorophenylalanine. Biosci. Rep. 7:121-127.

50. Leibowitz, S. 1986. Brain monoamines and peptides: role in the control of eating behavior. Fed. Proc. 45:1396-1403.

51. Nathan, C., and Roland, Y. 1990. Pharmacological treatments that affect CNS activity: serotonin. Ann. NY Acad. Sci. 600:277-296.

52. Lawton, C.L., and Blundell, J.E. 1993. 5-HT manipulation and dietary choice: variable carbohydrate (Polycose) suppression demonstrated only under specific experimental conditions. Psychopharmacology (Berl.) 112:375-382

53. Simansky, K.J. 1996. Serotoninergic control of the organization of feeding and satiety. Behav. Brain Res. 73:37-42.

54. Sakaguchi, T., and Bray, G.A. 1989. Effect of norepinephrine, 5-HT and tryptophan on the firing rate of sympathetic nerves. Brain Res. 492:271-280.

55. Shannon, N.J., Gunnet, J.W., and Moore, K.E. 1986. A comparison of biochemical indices 5-hydroxytryptaminergic neuronal activity following electrical stimulation of the dorsal raphe nucleus. J. Neurochem. 47:958-965.

56. Kalra, S.P., et al. 1999. Interacting appetite-regulating pathways in the hypothalamic regulation of body weight. Endocr. Rev. 20:68-100. 